\title{
Study on polymorphism of BMP-15 gene in Iranian native goats
}

Hamid Deldar-Tajangookeh, Ahmad Zare-shahneh, Mohammad Javad Zamiri, Ardashir Nejati-Javaremi, Mahdi Khodaie Sari Agricultural Science and Natural Resorce University, Sari, Islamic Republic of Iran Email: hamiddeldar@gmail.com

Introdction Different mutations in the bone morphogenetic protein-15 (BMP-15) and the Growth Differentiation Factor-9 $(G D F-9)$ genes have increased ovulation rate and infertility in a dosage-sensitive manner in sheep (McNatty et al, 2005). Five naturally occurring mutations in exon 2 of the sheep BMP-15 gene have been described. These mutations produce increased ovulation rate and twin and triplet births in heterozygotes, and complete primary ovarian failure in homozygotes resulting in total infertility in some prolific breeds of sheep (Galloway et al., 2000). However, information on genes affecting the fertility of Iranian goats is scarce. The goal of the present study was to examine the polymorphism of the $F e c X^{B}$ and $F e c X^{G}$ loci in $B M P-15$ gene in Iranian native goats.

Material and methods Jugular blood samples $(7 \mathrm{ml})$ were randomly collected from 109 Iranian native goats by using of EDTA coated tubes. Caprine genomic DNA was isolated from whole blood samples by using a commercially available kit. The final DNA pellets were resuspended in $50 \mu \mathrm{l}$ of sterile distilled water and stored in $-20^{\circ} \mathrm{C}$ for use. The $F e c X^{B}$ allele in exon 2 BMP-15 gene was amplified using the polymerase chain reaction (PCR) with primers forward: 5'GCCTTCCTGTGTCCCTTATAAGTATGTTCCCCTTA-3' and reverse: 5'-TTCTTGGGAAACCTGAGCTAGC-3' to amplify a 153 bp PCR product (Hanrahan et al., 2004). Amplification was for 30 cycles in a $25 \mu 1$ reaction mixture, with $100 \mathrm{ng}$ of caprine genomic DNA, $1 \mathrm{U}$ of Taq DNA polymerase and $2.5 \mathrm{mM}$ magnesium choloride at an annealing temperature of $57.5^{\circ} \mathrm{C}$. The PCR products were digested with $10 \mathrm{U}$ of DdeI enzyme (C/TNAG) overnight at $37^{\circ} \mathrm{C}$, and the resulting products were separated by $10 \%$ PAGE gel and visualized by silver staining. The resulting products of wild type animals will have a $122 \mathrm{bp}$ and $31 \mathrm{bp}$ fragments and the mutation type animals with $F e c X^{B}$ variant will have a $153 \mathrm{bp}$ fragment. A primer pair was also designed to detect SNP of the $F e c X^{G}$ allele in $B M P-15$ gene with Hinfl. The primer sequences were as follows; Forward: 5'-ACTGTCTTCTTGTTACTGTATTTCAATGAGAC-3'; and Reverse: 5'GATGCAATACTGCCTGCTTG-3'(Hanrahan et al., 2004). Polymerase chain reactions were carried out The amplification conditions for primers of the $\mathrm{Fec} X^{G}$ allele were as follows: denaturation at $94^{\circ} \mathrm{C}$ for 5 min; followed by 30 cycles of denaturation at $94^{\circ} \mathrm{C}$ for $30 \mathrm{sec}$, annealing at $63^{\circ} \mathrm{C}$ for $30 \mathrm{sec}$, and extension at $72^{\circ} \mathrm{C}$ for $20 \mathrm{sec}$; with a final extension at $72^{\circ} \mathrm{C}$ for $5 \mathrm{~min}$. The PCR products of $8 \mu \mathrm{l}$ were digested separately with $10 \mathrm{U}$ of $\mathrm{Hinfl}$ overnight at $37^{\circ} \mathrm{C}$ in a $20 \mu \mathrm{lreaction}$ mixture, and the resulting products were separated by $10 \%$ PAGE gel and visualized by silver staining. Primers amplified a $141 \mathrm{bp}$ band. The wild type products could be cleaved by Hinfl (G/ANTC) with a 112 bp and 29 bp fragments, the mutation type with $\mathrm{FecX}^{G}$ remained uncleaved.

Results.In the present study the PCR products were separated by $6 \%$ PAGE and following digestion with restriction enzymes were separated by $10 \%$ PAGE (Figure 1). The basic finding of the current study was the absence of polymorphism at the $F e c X^{B}$ and $F e c X^{G}$ loci of $B M P-15$ gene in Iranian native goats. All goats were monomorph for exon $2 B M P-15$ gene.
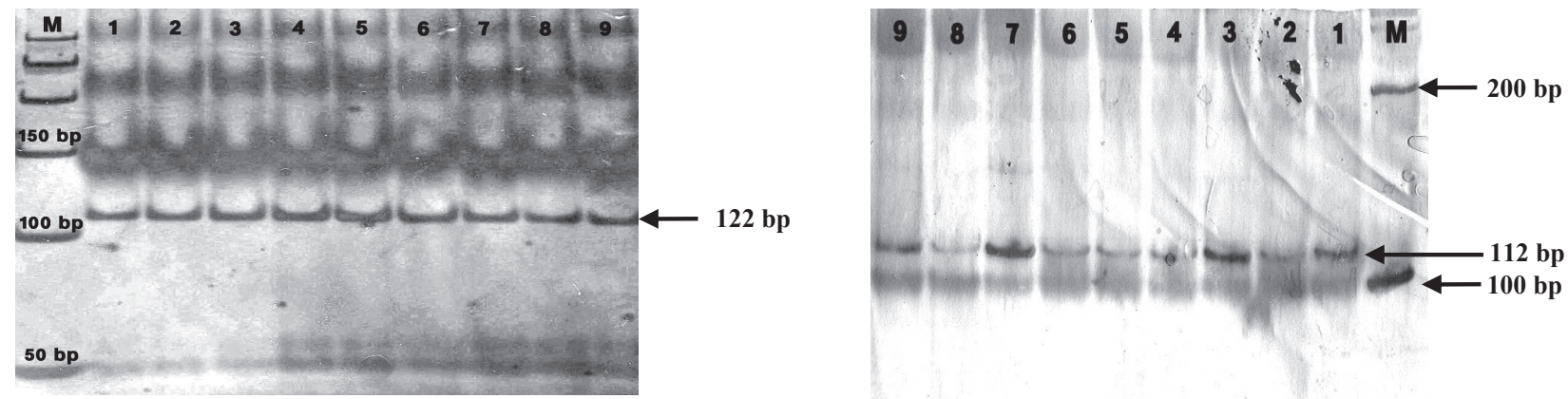

Figure 1 Polyacrylamide gel electrophoresis (10\%) images for PCR product of the Fec $X^{B}$ and Fec $X^{G}$ digested with $D d e \mathrm{I}$ and Hinfl, respectively.

Conclussion These results showed that there was no genetic polymorphism of $F e c X^{B}$ and $F e c X^{G}$ loci in $B M P 15$ gene in Iranian native goats. Further investigation should be directed at other loci of $B M P-15$ gene or other genes, using larger sample sizes.

\section{References}

Hanrahan, J.P., Gregan, S.M., Mulsant, P., Mullen, M., Davis, G.H., Powell, R., Galloway, S.M. 2004. Biology of Reproduction. 70, 900-909.

Galloway, S.M., McNatty, K.P., Cambridge, L.M., Laitinen, M.P.E., Juengel, J.L., Jokiranta, T.S., McLaren, R.J., Luiro, K., Dodds, K.G., Montgomery, G.W., Beattie, A.E., Davis, G.H., Rit, O. 2000. Nature Genetic. 25, $279-283$.

McNatty, K.P., Smith, P., Moore, L.G., Reader, K., Lun, S., Hanrahan, J.P., Groome, N.P., Laitinen, M., Ritvos, O., Juengel, J.L. 2005. Moecularl Cellular Endocrinolgy. 234, 57-66. 